\title{
The Biological Importance of Polynyas in the Canadian Arctic
}

\author{
IAN STIRLING
}

\begin{abstract}
Polynyas are areas of open water surrounded by ice. In the Canadian Arctic, the largest and best known polynya is the North Water. There are also several similar, but smaller, recurring polynyas and shore lead systems. Polynyas appear to be of critical importance to arctic marine birds and mammals for feeding, reproduction and migration. Despite their obvious biological importance, most polynya areas are threatened by extensive disturbance and possible pollution as a result of propesed offshore petrochemical exploration and year-round shipping with ice-breaking capability. However, we cannot evaluate what the effects of such disruptions might be because to date we have conducted insufficient research to enable us to have a quantitative understanding of the critical ecological processes and balances that may be unique to polynya areas. It is essential that we rectify the situation because the survival of viable populations or subpopulations of several species of arctic marine birds and mammals may depend on polynyas.
\end{abstract}

RÉSUMÉ. Les polynias sont des zones d'eau libre dans la banquise. Dans le Canada arctique, le polynia le plus vaste et le mieux connu, est celui de "North Water". Quelques polynias analogues mais de taille réduite existent; ils sont periodiques et peuvent être en relation avec le rivage.

Les polynias semblent primordiaux aux oiseaux marins arctiques et aux mammiferes, pour leur nourriture, leur reproduction et leur migration. En dépit de leur importance biologique certaine, la plupart des zones de polynias sont menacées d'une perturbation à grande echelle et d'une pollution possible, consequence des propositions d'exploration pétrochimique en mer et d'une navigation par brise-glaces, tout les long de l'année. Cependant, il est malaisé d'évaleur les effets de tels changements brutaux car à la date d'aujourd'hui, nous avons encore réalisé des recherches insuffisantes pour se permettre d'avoir une idée globale des transformations et équilibres écologiques critiques, peut être seulement valables à ces zones de polynias. Il est essentiel de redresser la situation; il en va de la survie de populations prosperes ou insuffisantes concernant quelques espéces d'oiseaux marins arctiques et de mammiféres dependant etroitement des polynias.

Traduit par Alain de Vendegies, Aquitaine Company of Canada Ltd.

\section{INTRODUCTION}

Polynya, sometimes spelled polynia, simply means an area of water surrounded by ice. Although polynyas occur in many locations in the sea ice of the Arctic and the Antarctic, suprisingly little really seems to be known and understood about them. The Pilot of Arctic Canada defines a polynya as any nonlinear-shaped opening enclosed in ice but adds the following detail, "polynyas may contain brash ice and/or be covered with new ice ... ; submariners refer to these as skylights. At times the polynya is limited on one side by the coast, and is called a shore polynya, or by landfast ice and is called a flaw polynya. If it recurs in the same position every year, it is called a recurring polynya", 
In terms of their biological significance, it is the recurring polynyas that are most important and they are the ones we will consider most extensively here. Recurring polynyas appear to fall into two types: those which are open throughout the winter and those which may be ice-covered during the coldest months in some years but which can be relied upon to have at least some open water early in the spring, usually by late March or early April, when the first migrating marine mammals or seabirds arrive.

Most of our knowledge of polynyas to date comes from historical sources such as the journals of explorers and whalers and from aerial surveys of sea ice conditions made in support of arctic shipping. More recently, studies are being conducted on currents and heat transfer problems associated with bodies of open water that remain unfrozen even when air temperatures plunge far below the freezing point (eg. Sadler, 1974). Although some ecological research has been initiated, our knowledge of the biological significance of polynyas is still limited to a number of more or less anecdotal accounts.

\section{TYPES OF POLYNYAS}

Polynyas vary greatly in size and shape and may be caused by a variety of factors, the most important of which are currents, tidal fluctuations, wind, upwellings or a combination of these factors. The largest and most famous polynya in the Canadian Arctic is the "North Water" of Smith Sound and northwestern Baffin Bay (Fig. 1) which was first reported by William Baffin in 1616 (see reviews by Nutt, 1969; Dunbar and Dunbar, 1972). During the winter, pack ice being carried south through Kane Basin by currents from the polar basin becomes congested and forms an impassable ice dam in Smith Sound between northeastern Ellesmere Island and northwestern Greenland. New ice formed to the south of the ice dam is apparently swept away by the southward flowing current, aided by the prevailing northerly winds, leaving open water behind it throughout the winter. Some scientists have speculated that the upwelling of warmer water from the northward flowing West Greenland current when it meets the supposedly denser colder polar water from the north is responsible for the creation of the North Water (eg. Brown, 1927), but this has not yet been demonstrated. Because of the ice dam, the northern limit of the North Water remains fairly constant between years but the southern limit, and consequently the size of the polynya, may vary greatly between years as a result of weather conditions. In some winters, open water or water covered only with young ice may extend south past the entrance to Jones Sound into the mouth of Lancaster Sound. For example, in late March 1974 , only young ice was present in Lancaster Sound as far west as Wellington Channel.

Smaller year-round polynyas are found in several areas of the Arctic. The sea ice in these areas is prevented from freezing over by the combined effects of tidal currents and wind, the effects of which are often magnified by geographic constrictions through which the water must flow. One of the best known of these smaller polynyas is the area of Cardigan Strait and Hell Gate 
between southwestern Ellesmere Island and northwestern Devon Island (Fig. 1). Dramatic testimony to the physical force of the currents there was given by Sverdrup (quoted by Taylor, 1955) who viewed Hell Gate in March 1900 and stated that, "none of us had ever seen waters so utterly impossible to navigate as the sound here", and "great hummocks were drifting along at terrific speed in a violent whirlpool caused by the strong tidal current". The Pilot of Arctic Canada (Canadian Hydrographic Service, 1970) warns that currents of three knots are not uncommon.

Similar polynyas of varying size occur in the area of northern Queens Channel and southern Penny Strait, Makinson Inlet, the eastern end of Bellot Strait (where there is also often a sizeable whirlpool), the eastern end of Fury and Hecla Strait, east of Hall Beach, and in the vicinity of the entrances to Frobisher Bay and Cumberland Sound (Fig. 1).

Throughout the Arctic, there are extensive systems of shore leads with variably sized areas of semi-permanent open water which are maintained largely by offshore winds and, to a lesser degree, by local currents. These lead systems may be frozen during part of the winter, particularly during periods with calm or onshore winds, but all are among the first areas in which open water occurs in the spring. Because these leads parallel the shorelines, they tend to be generally linear in shape and therexore differ a bit from the somewhat restrictive technical definition of a polynya. However, they are predictable in their location, recurrent, and among the most constant of areas in which open water may be found during winter and early spring. Because of the above factors, these lead systems are of enormous biological importance and therefore I will include them in this overview.

The most extensive and best documented of the shore lead systems lie along the east and west coasts of Hudson and James Bays, in Roes Welcome Sound between Southampton Island and the Keewatin coast, along the southern coast of Baffin Island from Cape Dorset east to Fair $\mathrm{Ne} s$ and from Big Island east to the Lower Savage Islands, and in the eastern Beaufort Sea (Fig. 1). A similar shore lead polynya system lies around the edge of the entire polar basin. Uspenski (1977) has called this zone the "Arctic ring of life".

\section{PRESENT BIOLOGICAL STUDIES OF POLYNYAS}

In recent years, large amounts of money have been spent by government and industry to gather biological data in some of the important areas where offshore petrochemical exploration programs are being undertaken or are being planned, and where year-round icebreaker and tanker traffic is being considered. Projects such as the Eastern Arctic Marine Environment Study and the Beaufort Sea Project have made valuable contributions. However, ecological baseline studies in arctic marine areas require several years to complete, possibly a decade or more. They simply cannot be done adequately in the 18 or 24 month periods for which funds have generally been available. Nonetheless, biologists in government departments and private consulting 
companies are now being put into the position of having to make vital decisions and recommendations on the basis of the available data, however limited. Equally important, these same biologists are having to make critical recommendations to their administrators on how best to utilize the ever dwindling pool of funds available for research in order to evaluate problems for which little time has been left to consider. Thus, the remainder of this article will attempt to review some of what we know about polynyas in the biological sense, in relation to some of the perceived environmental threats. More importantly, I will try to identify some of the aspects which are presently not well understood.

THE BIOLOGICAL IMPORTANCE OF POLYNYAS

\section{The North Water}

In terms of biological significance, the North Water is probably the most important polynya in the Canadian Arctic. Certainly, it is the largest and most permanent. Furthermore, because of the fact that the North Water is shared with Greenland, there are also international considerations to the conservation and management of the marine mammals and seabirds that depend on that area.

Although the evidence is largely circumstantial, it appears that the North Water may be an overwintering area for an undetermined number of white whales (belugas) and narwhals. It is currently estimated that during the summer, a third of North America's white whales and 85 percent of its narwhals enter Lancaster Sound, but the proportion of those that may overwinter in the North Water is unknown. It is possible that some of the surviving remnants of the bowhead whale population of the Eastern Arctic may winter there as well. No precise figures are available but walruses, ringed seals and polar bears are also abundant along the edges of this polynya during the winter months.

By late March or early April, the North Water polynya begins to spread south and west. The narwhals and white whales follow the ice edge closely, immediately penetrating new cracks and leads' as they develop. It appears that these whales are eager to exploit feeding areas from which they have been excluded by the ice cover all winter and they are willing to move far from open water early in the spring to do so. Their smooth backs lack a dorsal fin, apparently an adaption for breaking through young ice to facilitate continued breathing should a lead re-freeze after the whales have entered it. The instinct of these whales to follow leads away from the open water early in the spring makes them especially vulnerable to the Inuit hunters of Pond Inlet and Arctic Bay on northern Baffin Island who eagerly await their arrival. On both sides of the North Water, polar bears, seals and walruses also follow the ice edge as break-up proceeds.

By late April, the polynya is usually at least partially open as far west into Lancaster Sound as Prince Leopold Island. This large and apparently highly 
productive marine area, surrounded by extensive cliffs which are suitable for nesting, provides feeding areas for migratory colonial seabirds. As a result of this fortuitous combination of factors, Lancaster Sound is the annual host to several million seabirds of approximately 25 species, forming over 50 percent of the eastern arctic population. It is truly, as Tuck (1957) described it, one of the ornithological wonders of the world.

\section{Smaller Year-Round Polynyas}

Although the physical and biological scale is reduced in the smaller polynyas, they are probably no less important on a local basis and when considered in total. Variable numbers of walruses regularly overwinter in the polynyas at Cardigan Strait-Hell Gate, Penny Strait-Queens Channel, and in the eastern entrance to Fury and Hecla Strait (Loughrey, 1959; Kiliaan and Stirling, 1978; Davis et al., 1978). It is well known that ringed seals, bearded seals and polar bears are abundant in the vicinity of all these smaller polynyas through the winter as well. Because of the predictable presence of walruses in the polynya in northwestern Foxe Basin, the Inuit from Igloolik have become one of the only groups to hunt walruses during the winter. The hunt itself is a relatively specialized event in that it first requires a southeasterly wind to push the pack ice up against the edge of the fast ice on the east coast of Igloolik Island (Grainger, 1957). Under this circumstance, the walruses are concentrated in relatively small pools of water between the compacted ice floes. The hunt is a group effort, in which killing and processing are done at great speed so that the hunters can get back to shore before the wind changes and disperses the ice floes.

\section{Shore Lead Polynya Systems}

Shore lead polynya systems also appear to support higher densities of seals and polar bears during the winter than do the adjacent fast ice areas. Whenever the leads freeze over, the seals simply maintain breathing holes in the young ice, until the lead opens up again (Smith and Stirling, 1975). Consequently, it is easier for seals to breathe there while feeding than to maintain their own breathing holes in areas which are continuously frozen, or to compete for access at breathing holes being maintained by other seals. The moving ice appears to be the preferred habitat of bearded seals (Burns, 1967) and an area where subadult and possibly non-breeding ringed seals concentrate as well. Polar bears appear to be more abundant in these areas in which the ice continuously opens and re-freezes, partly because the seals are more abundant there and possibly also because the breathing holes are not covered deeply with drifted snow so that the seals are more vulnerable to predation (Stirling et al., 1975).

Shore lead polynya areas are usually the first to break up in the spring and consequently they become the main arteries for migrating marine mammals and staging areas for migratory waterfowl and seabirds. One of the best examples of a shore lead polynya system is the one which runs east-west along the southern Beaufort Sea, swings north parallel to the western coast of 
Banks Island and past the entrance to M'Clure Strait and along the western coast of Prince Patrick Island (Fig. 1). A large open water area known as the Cape Bathurst polynya forms almost every year, sometimes as early as mid-March between Baillie Island and Banks Island, in the area where the shore leads leave the mainland coast and swing north.

There are high densities of seals and polar bears in the shore lead polynya system of the eastern Beaufort Sea throughout the winter because of the unstable ice conditions, but it is in spring and early summer that the biological significance of the area is greatest. White and bowhead whales, that probably winter in the northern Bering Sea, enter the shore lead systems off western Alaska in March and April and begin to migrate east, arriving in the Cape Bathurst polynya by about late May (Fraker et al., 1978). The white whales feed there for about six weeks before moving again, this time westward to the Mackenzie River estuary to have their calves. Less is known about the bowhead whales but they also appear to feed in the Cape Bathurst polynya during the late spring and early summer. This distribution is confirmed from the kill records of the early whalers who used to overwinter in the Beaufort Sea, mainly at Herschel Island and sometimes further east, specifically to hunt bowhead whales in the Cape Bathurst polynya in the early spring (Sergeant and Hoek, 1974).

The presence of both the shore leads and the Cape Bathurst polynya in the southeastern Beaufort Sea in the early spring is also critical to the survival of the hundreds of thousands of migratory sea ducks that stage and feed there when they migrate north.

\section{What is the Ecological Significance of Polynyas?}

Although we have geographical information on polynyas and know some aspects of the biology of the marine mammals and birds that depend upon them, in terms of our understanding of the ecological importance of polynyas, we have not progressed very much further than the early arctic and antarctic explorers, most of whom noted the association between open water areas and an abundance of marine life. In one sense, our lack of detailed knowledge is not too surprising in that research in polynya areas is time consuming, expensive in terms of the logistic support needed, and sometimes dangerous. The sea ice in these areas is often weak because of the currents, which makes surface travel hazardous; poor visibility prevails during much of the winter because sunlight is reduced or absent; and the ice is liable to break up during strong winds. The abundance of polar bears around polynyas adds another element of potential concern to those who would travel and set up camps on the ice.

One of the most fundamental questions is whether or not it is just the open water that makes polynyas so important, or if they are more biologically productive as well. To gain some appreciation of this question we can briefly consider some areas in which polynyas do not occur and review what happened when some recurring polynyas were late in forming. 
The incredible densities of colonial cliff-nesting seabirds on northeastern and southeastern Baffin Island contrast markedly with their absence in the intermediate area where potential nesting habitat is unused. The absence of seabird colonies along the eastern coast of Baffin Island appears to be related to the lateness of break-up and the extent of the ice in the area between Broughton Island and north of Clyde. These factors appear to significantly shorten the period during which seabirds can feed adjacent to potential nesting sites so that breeding there is precluded (Brown et al., 1975). Similarly, Stonehouse (1976) has documented the association between polynyas and the distribution of penguin colonies in the Antarctic.

How critical the time of break-up can be to the breeding success of northern seabirds in the brief arctic summer was clearly demonstrated in 1978 when ice break-up in Lancaster Sound was considerably late and reproduction was delayed or very much reduced. The result was that certain species of seabirds were unable to successfully rear young and productivity was close to zero (Nettleship et al., 1979). In 1964, the shore lead polynya system in the Western Canadian Arctic was still frozen up when the migrating waterfowl arrived and an estimated one hundred thousand birds starved to death on the sea ice (Barry, 1968).

The influence of rapidly changing ice conditions on the availability of open water and, consequently, on populations of seals and polar bears has also been observed (Stirling et al., 1976; 1977). Apparently in response to severe ice conditions in the Beaufort Sea during the winters of 1973-74 and 1974-75, numbers of ringed and bearded seals dropped by about 50 percent and productivity by about 90 percent. Numbers and productivity of polar bears declined markedly as well because of the reduction in abundance of their prey species. The changes in ice conditions could have affected the seals in two ways. Firstly, because of the heavy and compressed ice, it may simply have been more difficult for the seals to maintain their breathing holes (they normally do so by abrading the ice with the heavy claws on their,foreflippers). Secondly, if the ice was thicker in the spring of 1974, and had fewer cracks and leads in it, less sunlight may have penetrated into the sea to stimulate primary production. At best, the Beaufort Sea apparently has a fairly low level of primary and secondary production and a relatively uncomplicated food chain. Consequently, changes at the lower trophic levels could have raiid and significant effects on higher organisms. Thus, it seems clear that the timing and reliability of occurrence of a particular polynya can be critical to marine organisms and ecosystems.

However, we must ask the question, is it only the presence of open water that is important or is there more to it?

The biomass of birds and mammals that migrate to Lancaster Sound to feed and, to a lesser degree, to all the other polynya areas, suggests that these areas may in themselves be richer and more productive. Based largely on circumstantial evidence, the apparently greater primary productivity of Lancaster Sound has been attributed to upwelling of subsurface nutrients (e.g. Bailey, 1956; 1957; Collins, 1962) but even this most fundamental aspect 
has yet to be demonstrated. A few years ago, as part of the North Water Project, it was planned to have an icebreaker overwinter in northern Baffin Bay to do studies of biological oceanography. Regretfully, that aspect of the research was cancelled, and we lost our lead time in that vital area of polar marine research.

One wonders, for example, if the area of open water, coupled with thinner ice in the vicinity of a polynya would permit more sunlight to pass into the water in the spring and stimulate greater levels of primary productivity than might otherwise occur. According to a recent review by Adams (1975) benthic and epontic production may be of equal magnitude to planktonic production, and Grainger (1975) noted that the rate of primary productivity in Beaufort Sea was subject to considerable annual variation, depending on sea ice conditions. How significant is the primary productivity which occurs in the polynya areas? Is the presence of strong currents, upwellings or downwellings sufficient to increase the supply of nutrients thus making the extent or thickness of the ice cover less important? A small amount of data from a preliminary study has suggested that Lancaster Sound may be more productive than surrounding waters (Sekerak et al., 1976) but data with which to evaluate the question critically do not exist. What would the effect of oil on the under-ice community of either area be? Adams (1975) suggested that oil under the ice would severely curtail the primary productivity of the epontic community but we do not know how significant that could be.

Over the years, many people have noted the often spectacular numbers of marine mammals and birds near the ice edge, or even adjacent to larger ice floes. To some extent this probably occurs because it is as close as seabirds and marine mammals can get to the under-ice (epontic) populations of invertebrates and polar cod that have not yet been exploited in that particular season. It is probably also because of these food resources that the whales and seabirds are found in many leads soon after they develop. Even later in the summer, whales and seabirds continue to feed intensively in any new areas when the ice breaks out. Thus, simple access to unexploited food resources may adequately explain the concentrations of seabirds and marine mammals along the ice edge. However, recent preliminary studies (Buckley et al., 1979) have suggested that the physical force of the wind moving off the ice onto the water may set up a current away from the ice which stimulates a localized upwelling and nutrient enrichment. This appears to result in a "situation similar to the so-called "edge effect" in terrestrial ecology. Clearly, the extent to which this occurs, and its significance if it does occur, need to be critically evaluated.

How constant are the locations of polynyas? We have already alluded to the effects of a few recorded annual fluctuations in parameters such as ice conditions, but what do long-term changes in things such as the locations or durations of polynyas resulting from natural causes mean? Studies in Greenland have demonstrated that long-term climatic fluctuations have resulted in large-scale changes in the distribution and abandance of marine mammals and in the distribution and the economy of the Greenlanders (Vibe, 
1967). In the Western Canadian Arctic, there is a small colony of thick-billed murres at Cape Parry, which may be a relic of a wider previous distribution. Certainly, it is the only known breeding colony between Alaska and the Eastern Arctic. Prior to 1970, what is now known as the Cape Bathurst polynya used to appear off Cape Parry by late May. Since 1970, the polynya appears to have shifted further west to the region of Cape Bathurst and Baillie Island as mentioned before (Barry, pers. comm.). Will the extra distance that adults have to travel for feeding influence the survival of their young and consequently that of the colony itself? Could murres survive the extra travel in an area where the sea was more productive than the Beaufort Sea apparently is? All these kinds of issues are matters of practical concern when Canadians are asked to make decisions that will affect the long-term future of seabirds and mammals in our arctic marine areas.

\section{Protection of Polynyas and Potential Threats to Their Biological Value}

Some international concern is now being expressed in terms of polynyas such as those in the Laptev Sea, near Spitsbergen, and the North Water. In Canada, although several of the ecological sites proposed by the International Biological Programme (IBP) include all or part of a polynya (Nettleship and Smith, 1975), none have yet been protected by legislation. The murre colony at Cape Parry is legally protected as a migratory bird sanctuary but no legislation protects their feeding habitat. Similarly, the boundaries of most actual and proposed National Parks in the Canadian Arctic go only to the tide line, although Auyuittuq National Park on southeastern Baffin Island includes some adjacent marine areas. However, several new and imaginative ideas, based to a large degree on the proposed IBP Sites (Nettleship and Smith, 1975), are being developed for areas in Lancaster Sound, which still leaves some room for optimism.

What then are the threats or concerns? Certainly, in the region of the Laptev Sea or Spitsbergen, no threats appear imminent. In Canada, however, the situation is very different. Some form of industrial activity is already underway or proposed for many of the biologically rich polynya areas discussed in this article.

In the Beaufort Sea, several exploratory wells have already been drilled and numerous operational problems continue to plague drilling operations. Gas well blowouts, unexpected pressure, a freshwater blowout, and a lost oil spill from a service vessel are but a few of the problems encountered to date. An environmental assessment showed that if there was an uncontrolled oil blowout, much of that oil would be carried by the currents to the area of the Cape Bathurst polynya (Milne and Smiley, 1976). Depending on the timing, the effects on waterfowl could be devastating. The effects on marine mammals and polar bears are more difficult to assess. However, when we consider that the bowhead whale population of the Western Arctic is classified as endangered, and we remember that a large proportion of those whales go east through the leads parallel to the Tuktoyaktuk Peninsula (where the drilling is taking place) to reach the Cape Bathurst polynya to feed, we 
can be concerned about the potential detrimental effects of offshore activities on the future of the bowhead whale.

The impact of heavy ice conditions and late break-up on seabirds and marine mammals has already been discussed. It seems reasonable that offshore petrochemical exploration might be more complicated during years in which heavier ice conditions prevail. Consequently, the potential threat to seabirds and marine mammals might be greatly increased if an oil blowout or spill occurred in a year in which numbers and reproductive rates were already depressed because of environmental conditions.

Offshore exploratory drilling for petrochemicals has also been proposed in Baffin Bay, Lancaster Sound, and Davis Strait. If the extent of the possible discoveries warrant it, production will almost certainly follow. There is general agreement that an oil blowout, or spill at the wrong time, or chronic pollution associated with production in Lancaster Sound could be devastating to the seabirds (Milne and Smiley, 1978). There is less agreement about whether or not such an event would be detrimental to marine mammals or polar bears but the germane point to the whole discussion is that we don't know. Nor do we understand the ecological interrelationships of the different components of the marine community that might enable us to make reasonable predictions about the consequences of various theoretical scenarios. Yet we appear to be willing to make long-term, possibly irreversible, decisions that affect these areas. After the public hearings co,ducted in Pond Inlet, the EARP (Environmental Assessment Review Process) Panel recommended that no drilling take place for at least one more year. However, in his book Oil Under the Ice, Pimlott et al. (1976) suggested that Lancaster Sound might be so biologically rich and valuable as to justify a complete ban on petrochemical exploration.

It is often suggested that the eastern arctic waters are richer and more productive than those of the Beaufort Sea, but even this basic aspect is not well documented. However, if we assume for the purposes of this discussion that the statement is true, we are left to wonder how much more important any additional primary productivity or nutrient upwelling, resulting from the occurrence of polynyas, could be to an already impoverished sea such as the Beaufort Sea or how different the possible effects of massive or chronic pollution could be in either area. Again we don't know.

Extended season and even year-round operations by large specially constructed icebreakers have been proposed in several arctic marine areas, such as the Northwest Passage, for a variety of reasons. The Soviet Union has already clearly demonstrated its capability in polar icebreaking and it is clear that Canada has a national need in this area as well. The construction of an interisland gas pipeline would require at least an extended season icebreaking capability if only for hauling materials. Under another proposal to remove natural gas from the Queen Elizabeth Islands, natural gas would be liquefied at a plant on Melville Island and shipped via Barrow Strait and Lancaster Sound throughout the year in specially built icebreaker tankers. Another possibility is that if a large-scale offshore oil field is discovered in the 
Beaufort Sea, that the oil may be taken out through the Northwest Pasage on a year-round basis, in specially built tankers or under icebreaker escort. Any year-round icebreaker traffic will obviously seek to make maximum use of polynyas and shore lead systems because of the greater ease of travel. The potential consequences of either the simple physical disturbances or the possible attendant threats of catastrophic and chronic oil spills are not understood.

One example of a potential problem related to winter icebreaker travel from the North Water west through the Northwest Passage relates to whales. The penchant that whales have, in the spring at least, for leaving open water to follow new leads is well documented. Similarly, whales will sometimes follow in the wake behind icebreakers as they travel through pack ice, or enter fresh channels cut by icebreakers into ports prior to break-up in order to advance the shipping season. Some biologists are concerned that whales may follow icebreakers away from polynya areas during the winter and become restricted to unnatural isolated patches of water left in the wake of the ships where they might perish if the lead froze over again. The validity of this concern is clearly illustrated by records of white whales, narwhals and even of bowheads suffering mass mortality as a result of becoming stranded in an area in which they were eventually unable to maintain a breathing hole and continue to feed successfully. In the fall of 1979, over 100 narwhals (mainly females and young) were stranded by freeze-up in Agu Bay near Igloolik. Even though this represented a unique opportunity to gather data on the age and sex composition of a group of whales that actually became stranded in this fashion, no specimens were collected when the pod was exterminated by Inuit hunters. Similarly, alterations in the geographic location of the floe edge adjacent to certain polynyas might upset the delicate balance between the feeding and breeding areas in some colonial cliff nesting seabirds.

\section{SUMMARY}

One general principle remains. The arctic marine habitat is not uniform in terms of its biological productivity or in the distribution of the species at all trophic levels. Although the ecological reasons are not fully understood, it is probable that the most important arctic marine areas are those that contain polynyas. It is also an ecological axiom that if we conserve the habitat, the species will probably be able to look after themselves. This, then, is the point we are at in terms of arctic marine ecosystems in general. We are fairly knowledgeable on aspects of the biology of several species, in particular of the higher vertebrates, but we are not on nearly as firm ground when it comes to our knowledge of invertebrates or fish. Nor is our competence very great when it comes to being able to assess or predict the effects of our present or proposed activities on the arctic marine ecosystem. Although there may not still be sufficient lead time to complete enough meaningful work before decisions are required, one of the most important areas to examine is the 
ecological significance of the polynyas, for I suspect they may be critical to the survival of viable populations or subpopulations of several species.

\section{ACKNOWLEDGEMENTS}

In writing this article, I have relied greatly on discussions with colleagues who have worked in the Arctic for many years, and most of whom are still working there, including the following: Dr. Tom Barry, Canadian Wildlife Service; Dr. Max Dunbar, McGill University; Ms. Moira Dunbar, Defence Research Board; Mark Fraker, LGL Consulting; Dr. Ted Grainger, Arctic Biological Station; Dr. Steve Johnson, LGL Consulting; Dr. Lynn Lewis, Frozen Sea Research Group; Bill Markham, Ice Forecasting Central; Al Milne, Ocean Sciences; Dr. David Nettleship, Canadian Wildlife Service; Dr. Tom Smith, Arctic Biological Station; Dr. Christian Vibe, Copenhagen University Museum. I also thank Pauline Smith for constructive criticism of the manuscript and drawing the map. Over the years, the Canadian Wildlife Service and the Polar Continental Shelf Project have supported my own work with polar bears and seals in several polynya areas in the Canadian Arctic.

\section{REFERENCES}

ADAMS, W. A. 1975. Light intensity and primary productivity under sea ice containing oil. Final Report to Beaufort Sea Project. Fisheries and Marine Service, Victoria, B.C. 156 pp.

BAILEY, W. B. 1956. On the origin of deep Baffin Bay water. Journal of the Fisheries Research Board of Canada 13:303-308.

—. 1957. Oceanographic features of the Canadian Archipelago. Journal of the Fisheries Research Board of Canada 14:731-769.

BARRY, T. W. 1968. Observations on natural mortality and native use of eider ducks along the Beaufort Sea coast. Canadian Field Naturalist 83:140-144.

BROWN, R. G. B., NETTLESHIP, D. N., GERMAIN, P., TULL, C. E., and DAVIS T. 1975. Atlas of eastern Canadian seabirds. Canadian Wildlife Service, Ottawa. 220 pp.

BROWN, R. N. R. 1927. The Polar Regions: (New York: E. P. Dutton \& Co.) 245 p.

BUCKLEY, J. R., GAMMELSROD, T., JOHANNESSEN, J. A., JOHANNESSEN, O. M., and ROED, L. P. 1979. Upwelling: Oceanographic structure at the edge of the arctic ice pack in winter. Science 203:165-167.

BURNS, J. J. 1967. The Pacific bearded seal. Federal Aid in Wildlife Restoration Project. Covering invest. completed by Dec. 31, 1966. 3:1-66.

CANADIAN HYDROGRAPHIC SERVICE. 1970. Pilot of Arctic Canada. Volume 1, second edition. Department of Energy, Mines and Resources, Ottawa. 247 pp.

COLLIN, A. E. 1962. The oceanography of Lancaster Sound. Ph.D. Thesis, McGill University, Montreal. $204 \mathrm{pp}$.

DAVIS, R. A., KOSKI, W. R., and FINLEY, K. J. 1978. Numbers and distribution of walruses in the central Canadian High Arctic. Unpubl. Rept. by LGL Ltd. for Polar Gas Project, Toronto. 50 pp.

DUNBAR, M. and DUNBAR, M. J. 1972. The history of the North Water. Proceedings of the Royal Society (B) 72:231-241.

FRAKER, M. A., SERGEANT, D. E., and HOEK, W. 1978. Bowhead and white whales in the southern Beaufort Sea. Final Report to the Beaufort Sea Project. Fisheries and Marine Service, Department of the Environment, Victoria, B.C. 114 pp.

GRAINGER, E. H. 1975. Biological productivity of the southern Beaufort Sea: the physical-chemical environment. Final Report to the Beaufort Sea Project, Fisheries and Marine Service, Victoria, B.C. 82 pp.

1957. The "Calanus" in Foxe Basin, 1955-56. Arctic Circular 9:41-43.

KILIAAN, H. P. L. and STIRLING, I. 1978. Observations on overwintering walruses in the eastern Canadian High Arctic. Journal of Mammalogy. 59:197-200.

LOUGHREY, A. G. 1959. Preliminary investigation of the Atlantic walrus Odobenus rosmarus rosmarus (Linneaus). Canadian Wildlife Service. Wildlife Management Bulletin Series No. 14. 123 pp. 
MILNE, A. R. and SMILEY, B. D. 1976. Offshore drilling for oil in the Beaufort Sea: A preliminary environmental assessment. Beaufort Sea Project, Department of Environment, Victoria, B.C. 43 pp.

1978. Offshore drilling in Lancaster Sound: Possible environmental hazards. Department of Fisheries and Environment, Sidney, B.C. 95 pp.

NETTLESHIP, D. N., BIRKHEAD, T. R., and GASTON, A. J. 1979. Reproductive failure among arctic seabirds associated with unusual ice conditions in Lancaster Sound in 1978. Unpublished report of the Seabird Research Unit of the Canadian Wildlife Service, Dartmouth, Nova Scotia. $29 \mathrm{pp}$.

NETTLESHIP, D. N. and SMITH, P. A. 1975. Ecological sites in northern Canada. Canadian Committee for the International Biological Programme. Conservation Terrestrial - Panel 9, Ottawa. 330 pp.

NUTT, D. C. 1969. The North Water of Baffin Bay. Polar Notes 9:1-25.

PIMLOTT, D., BROWN, D., and SAM, K. 1976. Oil under the Ice. (Ottawa:Canadian Arctic Resources Committee.) $178 \mathrm{pp}$.

SADLER, H. E. 1974. On a polynya in Makinson Inlet. Arctic 27:157-159.

SEKERAK, A. D., BUCHANAN, R. A., GRIFFITHS, W. B., and FOY, M. G. 1976. Biological oceanographic studies in Lancaster Sound. Unpubl. Rept. by LGL L.td. to Norlands Petroleums Ltd. $169 \mathrm{pp}$.

SERGEANT, D. E. and HOEK, W. 1974. Seasonal distribution of bowhead and white whales in the eastern Beaufort Sea. In: Reed, J. C. and Sater, J. E. (eds): The Coast and Shelf of the Beaufort Sea. Arlington, VA:Arctic Institute of North America, pp. 705-719.

SMITH, T. G. and STIRLING, I. 1975. The breeding habitat of the ringed seal (Phoca hispida): The birth lair and associated structures. Canadian Journal of Zoology 53:297-1305.

STIRLING, I., ANDRIASHEK, D., LATOUR, P., and CALVERT, W. 1975. The distribution and abundance of polar bears in the eastern Beaufort Sea. A final report to the Beaufort Sea Project. Fisheries and Marine Service, Department of the Environment, Victoria, B.C. 59 pp.

STIRLING, I., ARCHIBALD, R., and DEMASTER, D. 1977. Distribution and abundance of seals in the eastern Beaufort Sea. Journal of the Fisheries Research Board of Canada 34:976-988.

STIRLING, I., PEARSON, A. M., and BUNNELL, F. L. 1976. Population ecology studies of polar and grizzly bears in northern Canada. Trans. 41 st. North American Wildlife Conference 41:421-430.

STONEHOUSE, B. 1967. Occurrence and effects of open water in McMurdo Sound, Antarctica, during winter and early spring. Polar Record 13:775-778.

TAYLOR, A. 1955. Geographical discovery and exploration in the Queen Elizabeth Islands. Canada Dept. Mines and Tech. Surv. Geog. Branch. Memoir 3:1-172.

TUCK, L. M. 1957. Wildlife investigations in the Cape Hay Region, Lancaster Sound, 1957. Unpublished Canadian Wildlife Service Publication No. 760. 39 pp.

VIBE, C. 1967

Arctic animals in relation to climatic fluctuations. Meddelelser om Grønland 170(5). $227 \mathrm{pp}$. 